\title{
Origin and development of the family carers' movement in the United Kingdom in the 20th century
}

\begin{abstract}
The history of the carers' movement in the United Kingdom began in the second half of the 20th century. Demographic, social, and cultural changes in the UK made it necessary to define the role of a family carer in light of the needs of an ageing population. The Carers UK organisation, together with government representatives and researchers, fought for recognition and understanding of the challenges faced by carers, recognition of the rights for carers, as well as adoption and dissemination of the term 'carer' in social awareness. The main purpose of the essay is to show the origin of the family carers' movement in the UK in the 20th century, and the integration process of different entities. The presented information can be an example for other countries facing similar challenges with informal care of those who are dependent due to age or illness.
\end{abstract}

Palliat Med Pract 2020; 14, 1: 26-34

Key words: family carer, caregivers, informal care, Carers UK, ageing society, palliative care, volunteering

\section{Introduction}

In February 2019 the largest news websites in the UK announced that more than 600 people in the country quit their jobs every day to look after elderly and disabled relatives [1]. The figure was the result of a study carried out by Carers UK at the turn of 2018, which showed that as of the $4^{\text {th }}$ January 2019, an estimated 2.6 million people gave up work to start caring for family members; and of those, nearly half a million had taken this step in the previous two years [2]. These figures demonstrate the scale of the phenomenon by drawing attention to the challenges of our civilisation.

The definition of 'family carer' used in this article is defined as follows: a family member who, free of charge, takes care of a close relative; this close relative is dependent on him or her due to sickness or infirmity and requires regular and continuous help for a substantial number of hours per week. This support consists of emotional support, assistance with everyday activities, performing basic or more advanced personal care requirements - depending on the level of need. The term 'informal carer' refers to an adult who is not related to the person he/she is caring for but who performs the same function [3]. In the literature, these terms are differentiated on the basis of family ties. However, in the second half of the 20th century in the UK, these terms were used interchangeably and referred mainly to family care. This was due to the very low level of knowledge on the subject and the fact that the word 'carer' itself

\footnotetext{
Address for correspondence:

Martyna Klimek

Fort Community Centre, Health and Social Care

25 North Fort Street

EH6 4HF Edinburgh, Wielka Brytania

e-mail: martynaklimek@gmail.com
} 
was a new concept; this is more widely presented in the following sections of this paper. These terms will be used interchangeably in this article.

As a result of numerous social and cultural changes in the 20th century, the United Kingdom has been struggling with the consequences of an ageing population for many years, including an increase in the age and the population of family carers. It is extremely important and interesting that the subject of family care is widely known in British society and has been studied there for many years. Caroline Glendinning and Gerhard Igl in the 2009 study Long-term Care in Germany and the UK draw attention to the fact that the United Kingdom is one of the few countries where carers receive benefits in their own right - rather than indirectly through an allowance to the person they care for, as is often the case [4]. This came about as a result of work carried out in the 20th century by politicians, researchers, and organisations. They gradually transformed the private issue of family care into a social problem, creating a support system that integrates various care providers.

The country has come a long and difficult way in the battle for the rights for carers and in building public awareness in British society. Although the family carers' movement began in the 1960s, many key questions remained unanswered more than 20 years later. In 1988, Cherrill Hicks, in a touching introduction to his book Who cares? Looking after people at home, pointed to a growing number of family carers and summarised the state of social and political knowledge in relation to informal carers: "There is in Britain a growing group of people, mainly woman, who have aptly been described as a forgotten army. They are the carers - over one million women and men - who have given up much of their lives to look after disabled and elderly dependants. (...) What do we know about carers? Very little. We know that at present there are around 1.3 million people looking after an elderly or disabled relative virtually as a full-time job, and five or six million more for whom caring is a major responsibility. We know the most of them - three out of every four - are women, usually the daughters, wives, and mothers of their dependants. We know that in most families it is usually one person, and one alone, who takes on the job of carer, with little or no support from other family members, friends, neighbours, or statutory services. (...) We know that caring is a long-term commitment, which can be measured in years rather than months (...). And we know that by keeping their dependent relatives out of institutions, carers save the British state over $f 11$ billion a year. Of course, there have always been people, mostly women, who have given up their lives to look after a disabled parent or child. But in the past, this role has been accepted as an extension of women's normal responsibilities, as a natural sacrifice taken on out of love and duty. It is only in the last few years that these people have been given what now amounts to and almost official title - 'carer' — and that their needs have begun to be taken seriously by the government. Why? Because caring is in crisis, and because carers are saying they can no longer cope" [5].

From the work done in the UK we can draw inspiration for institutional and social initiatives emerging in Poland in relation to family care of people who are dependent, chronically ill, or at the end of their lives.

Learning about the social-demographic changes and the historical background of the development of this movement in the UK can help to understand the stage Poland is currently at in the context of family care. The problem of family care in Poland has been noticed, but as pointed out by Anna Janowicz, president of the Hospice Foundation and an initiator of numerous activities for dependents and their carers, there is a lack of comprehensive and satisfactory information on informal care for people at the end of their lives in Poland [6]. Social and political activities carried out on a large scale in the UK as well as numerous studies, which are a source of data enabling estimations on the scale of needs, can be an inspiration both for people creating social policy in Poland and for non-governmental organisations supporting family carers, and above all, carers whose efforts should be recognised and supported both by care systems and by local communities.

\section{Social-cultural factors and the population of carers in the UK}

To understand the reasons behind the increase in the number of dependent people and their carers in the United Kingdom, it is important to learn about the demographic, social, and cultural changes that have affected the country. In the literature and studies on the care of dependent people, the main factors impacting current challenges are the processes of the aging society.

Population aging is a topic present in international social discourse as well as in the area of social sciences: psychology, pedagogy, and social work, and is the subject of sociological research. An aging society is not a new phenomenon, and it has become a common problem since the second half of the 20th century. In 1982, the First World Assembly on Ageing was held in Vienna [7]. The short summary, made available by the UN Information Centre in Warsaw, included the most important messages from this meeting: "during 
the meeting it was emphasised that the phenomenon of aging societies (...) most severely hits the developing societies and those in the transition period. This has serious social, economic, and cultural effects. It has been noted that many countries do not have programs designed to address the needs of a rapidly growing elderly population. The need to ensure that older people participate in social and family life, self-fulfilment, and an adequate standard of living has been stated. The above postulates were included in the International Action Plan on the Issue of Aging Societies developed by representatives of 250 organisations and 121 nations" [8].

In the middle of the 20th century, the largest percentage of people over the age of 65 lived on the North American (8.2\%) and European (8\%) continents. In the mid-1960s Europe overtook North America in the percentage of old people in the population - reaching 10\%. The increase in the percentage of elderly people in the world began to intensify in $1990-6.2 \%$ of the entire world population was old. The percentage of the elderly population was still greatest in Europe and amounted to 13.5\% [7]. These summary statistics show the dynamics of demographic change that particularly affected European societies. The consequences of these changes are the growing number of dependant and elderly people at home, as well as their carers.

The United Kingdom has been strongly affected by the increase in the elderly population. In 1901, around 0.8 million men and 1 million women were aged 65 and over. By 1981, these numbers had increased to 3.3 million men and 5.1 million women [9].

One of the reasons for the aging of society, which is also a factor directly affecting the problems of family care, is a decrease in birth rates associated with increasing childlessness. The percentage of childless women in the UK increased from $11 \%$ among those born in 1942 to $18 \%$ for people born in 1969 [10]. Already in 1985, Gillian Parker notes that family size is steadily decreasing while the number of childless marriages is increasing, which will have a major impact on the potential caregiver population; more older couples will not have a direct relative to take care of them or fewer adult children would share caring responsibilities for older parents [9].

In literature regarding the challenges of family care in the UK, great emphasis is placed on changes in the family structure, which significantly affect the problems in providing care to dependent people. In the last decades of the 20th century, the United Kingdom, like many developing countries, witnessed an evolving pattern of changes in family structure, its roles and relationships. People's attitudes towards marriage, cohabitation, single parenthood, divorce, and childlessness changed. Marriage, despite still being considered a dominant form of the family, ceased to be considered the only framework where you can live as a family and have children [11]. There was also a significant decrease in the durability and homogeneity of long-term relationships between couples. Unmarried partnerships and childbearing outside relationships have become increasingly common. The relationships themselves - regardless of whether married or in partnership - are less stable [11].

A new social threat to aging is the change in family structure. Monika Reichert and Judith Phillips, in their work from 2009 The changing generational contract within and outside the family: Britain and Germany compared, point out that families are not necessarily a group of biologically connected people anymore; they are becoming increasingly complex. Changes in the behaviour, attitudes, and lifestyles of people in the United Kingdom in the 20th century have left implications for families and intergenerational relations. The authors point to, above all, the growing number of people who live alone all their lives; more couples who have never been married or have no children; the growing number of divorces and remarriage; the increased participation of women in the labour market and the increasing number of family members living at great distances from each other [12]. Gillian Parker in 1985, when analysing the changes in family structure, noticed that one of the significant factors that may affect the potential pool of carers is the increase in the number of divorces and remarriages. In 1961, the number of divorced individuals per 1000 married couples was 2.1, and in 1980 it increased to as much as 12 . One of the results of re-selection of partners may be blurring the line of responsibility for caring for parents and parents-in-law [9]. In the context of family structure changes, it is worth mentioning that the number of single-parent households in the UK has also increased. In 1961, there were 367,000 single parents with at least one dependent child, and in 1971 there were already 515,000 of them [9].

When analysing the history of social changes in the UK in the 20th century in relation to informal family care, it can be noted that a key factor for the changes is the evolution of the role of women in the family and society after World War II. In the post-war years, it was assumed that women were natural carers and that all family carers were women. The perception of women as caregivers was one of the foundations of the welfare state, which followed the vision of a man - a breadwinner and a model housewife [13]. Gillian Parker in 1985 wrote that politicians who are unaware or ignore the changes taking place in the 
country are at high risk of creating inappropriate laws and services. She gave an example of expectations regarding women's lives in the post-war period in the UK - it was assumed then that a single woman, despite the fact that the percentage of single people in the country's population had declined over the previous 50 years, would still be available to care for the elderly. Post-war social security legislation assumed that most women would be married and thus financially dependent on their husbands. In this way, the scale of the problem was incorrectly assessed; both in the case of women's participation in the labour market and the increasing number of divorces [9].

The mass entry of women into the labour market changed the standard work-sharing model in families. Working at home, caring for children and the elderly, which was previously carried out free of charge by women, had to be provided from outside - for a fee or through granted benefits. Despite the fact that men began to play an increasingly important role in providing care, women were usually still expected to act as carers where there were no proper formal services [11]. For comparison, in 1961 married women constituted about $16 \%$ of the total workforce, and in it was predicted that in 1981 they would constitute $25 \%$ of the total [9]. Studies by the Office of National Statistics show that employment of women increased from $53 \%$ in 1971 to $67 \%$ in 2013 [14].

These social changes are considered to be a result of the sexual revolution in the 20th century. Between 1955 and 1975, the British government began to control population growth by ultimately providing contraception for all women and men, regardless of age and marital status [15]. The contraceptive pill introduced, in 1961, the ability to control potential pregnancy; the subsequent change in attitudes towards sexuality, previously functioning mainly in the context of marriage, resulted in lowering fertility levels; marriage was perceived as one of several options, and the existing definition of the family began to become increasingly fluid [15].

The aforementioned analyses help to understand the demographic changes that have occurred in the United Kingdom, and the challenges and difficulties of social policy in meeting the requirements of the aging population. The increase in the number of older people and the decrease in the number of potential carers meant a greater demand for care, and this obligation rested mainly on family carers. In this context, however, one should not forget about the support from hospitals and care facilities, which were and are one of the solutions to the problems of informal care.

It is worth mentioning that one of the forms of such support is palliative and hospice care, which has its origins in the United Kingdom in the 20th century. In the pursuit of social education with regard to terminally ill people - and to ensure proper care for terminal patients - professional medical and nursing care was combined with care for the non-medical needs of patients and their families, as well as team training [16]. These were the initial and successful attempts to include families in the integrated care system.

The increase in the popularity of care facilities has been, to some extent, a response to the demographic changes that have occurred in the UK, but the process of an aging society, changes in family structure, decrease in birth rates, and the evolution of the role of women have contributed to the social change, which made it necessary to define the role of a family carer. The existing assumption that a woman is a natural caregiver was recognised as incorrect, and the subject of family care from a private matter evolved into a social problem.

\section{First supporting organisations, awareness-raising, and the fight for the carers' rights in the UK}

Joyce Cavaye in her book Hidden Carers [17] points out that the role of informal carers in today's understanding has become noticeable as a result of two related elements. The first is the research and studies, which were dealt with by politicians and social researchers; the second factor is the pressure groups, which, according to Cavaye, played a key role in building social and political awareness [17]. The Carers UK organisation was the first charity organisation to fight for the rights and recognition of family carers since the early 1960 s. Today, after over 50 years of its activity, it is still the largest organisation supporting carers, and it is worth going back to the beginnings of its creation to understand how far it has come in the battle for changing carers' quality of life.

In 1963, pastor Mary Webster wrote a letter to a local newspaper about the difficulties of working and at the same time caring for aging parents. In 1954 , at the age of 31 , she quit her job to take care of them. After almost 10 years she shared her story, successfully publicising the story about difficult experiences of female carers, who were struggling not only with financial problems, but also with isolation. At that time, further articles appeared: Single and Silent written by May Abbott in the Guardian in 1963, and Single - but certainly not carefree written by Rosemary Small, and many others in a similar vein [18]. These were the first movements building social awareness in relation to carers, but still focused only on women. 
In 1965 Webster founded the National Council for the Single Woman and Her Dependents (NCSWD) organisation [19]. From the very beginning the organisation was focused on direct cooperation with carers and wanted to learn as much as possible about them. The results of the publication of the 1963 article reassured Webster that the topic of family care was a great social problem that should be publicised; she received hundreds of letters from women in similar situations, who had dedicated their lives to the care of others. Shortly after founding the NCSWD, the first survey was conducted, with as many as 700 carers included [18]. Over the following years, the organisation was running campaigns and cooperating with politicians on expanding existing, and creating new, rights for carers.

A significant achievement of all individuals and organisations active at that time was the campaign and the introduction of the Invalid Care Allowance in 1976. This was to protect the current income and future retirement benefits of labour market participants whose full-time employment was terminated prematurely due to caring for elderly relatives [20]. It was probably the first significant gesture of central government towards carers. However, focusing on financial problems related to leaving work, the benefit was not payable to married women - it was assumed then that married women do not work and stay at home [21].

In 1981, another organisation was formed: the Association of Carers. The association was founded by Judith Oliver, who was taking care of her disabled husband. She believed that there was a need for an organisation that would support all carers, not just carers for the elderly [19]. The Association of Carers began to fight for the extension of the Invalid Care Allowance to married women, defining a carer as anyone who is living a limited life due to caring for a mentally or physically handicapped person or a dependent person due to their advanced age. The organisation's goal was also to draw attention to the needs of carers, which are just as important as the needs of the people they care for [22]. In the meantime, NCSWD changed its name to the National Council for Carers and Their Elderly Dependants. Two organisations competed against each other for a few years, but in 1986 they merged to form the Carers National Association [22]. It is worth adding that the name of the organisation puts the word 'carer' first. It was a deliberate decision, which demonstrated by the name itself the importance of the work of carers, symbolically giving them priority [18]. The new organisation became a strong pressure group and played a key role in introducing changes to the legislation for carers [17].
Family carer in the UK - recognising the change in the role of women and forming the definition

The campaign carried out by the Association of Carers in 1981, to extend the Invalid Care Allowance to married women, highlighted the end of the care issue. As a result, the assumption that women naturally and voluntarily provide family care started being seriously questioned. In particular, attention was drawn to how these expectations prevented middle-aged women from returning to paid employment after leaving care. In response to this concern, the Equal Opportunity Commission presented the first reliable assessment of the unpaid and unrecognised contribution of women to informal care [22]. The commission admitted that it expected families to provide care for the vast majority of the disabled, sick, and elderly. The obligation of care usually rests on the women who are closest to the people in need of care [23].

The changing role of women in the family and in society was a fundamental element in the creation of a carers' movement and, as a result, a discussion on the definition of the term 'carer'. Bill Bytheway and Julia Johnson in the 1998 study The Social Construction of Carers noticed that less than 40 years ago the term 'carer' was barely known in the English language. It was especially difficult to understand for those who considered themselves as caregivers and devoted themselves to taking care of the sick or the disabled. For people with such experience, the thought of being a carer was a social invention. People in the same situation in the 1950s would not have considered themselves to belong to a special category of people. The term 'carer' would have been an alien concept. For this reason, we can think of the British carers' concept as a social construction, a category created through the interaction between individual experience and various interest groups - politicians, researchers, and pressure groups [22].

In 1981, the newly elected Conservative government began to promote 'community care'. The official document issued by the Department of Health and Social Security confirmed that basic sources of support and care for the elderly are informal and voluntary; they come from personal ties of kinship, friendship, and neighbourhood and are irreplaceable. However, it was emphasised that the role of public authorities is to maintain and, if necessary, develop - but never replace - such support and care [24]. It is worth adding that this view was shared by the interested parties themselves as well as their relatives and friends. After introducing the policy, it was anticipated that the money saved on institutional provisions would be 
used to create an integrated network of health and social services in the community. However, despite the increase in these services, it was still recognised that the main support for dependent people in the community was provided informally by their families and friends [25].

Despite the fact that the word 'carer' did not appear in official documents, it was considered that care can involve significant personal sacrifice, especially when 'family' usually means one person - often a single woman, caring for an elderly relative [24]. The concept of the government and the promotion of 'community care' were widely interpreted as female care. Based on this, a number of scientific studies have been developed, many reports and seminars have received titles such as "Caring for the carer", and the term began to be used more and more frequently in official documents, and by 1989 the word 'carer' was officially recognised in professional vocabulary [17, 22].

It is worth noting at this point that in Polish literature on the subject, definitions of family and informal carers have begun to appear; but as emphasised by Anna Janowicz, "there are no universally applicable definitions of, or consensus on, these concepts in the differentiation between researchers, social policy makers, or service providers. It can be assumed that 'informal care' is a broader concept than 'family care', because in addition to family members it also includes volunteers, neighbours, and other people from local communities. Topics related to the situation of informal carers usually appear in the context of the organisation of care for dependent elderly people" [6]. The recognition of these important concepts, commonly used in international literature, gives hope that their place will be well established in science and care practice, and as a consequence they will also become widely known and used in Poland.

\section{The 1985 General Household Survey - a breakthrough after nationwide research on carers in the UK}

In the early 1970s in the United Kingdom, researchers began to wonder how to count the number of people who look after others - the data was therefore based on the number of people in need of care. At the time, it was estimated that there could be almost a million adults with special needs living with other people, who were supposed to provide at least some support. Together with carers who were supporting severely disabled children, the estimated population of carers was close to 1.2 million [9].

A breakthrough in understanding the term 'carer', and the scale of the previously unnoticed challenge, was a study conducted by the General Household Survey in 1985. At the request of the Department of Health and Social Security, a series of questions were included in the general household survey to identify people who were caring for the sick, disabled, or elderly. The main purpose of the survey was to estimate the number of people providing informal care and the number of carer subgroups. Information was collected from a representative country-wide sample of approximately 18,500 adults living in private households in the UK. Carers were defined as individuals who looked after or provided regular services to the sick, disabled, or elderly living on their own or in another household [25].

The General Household Survey of 1985 was the first authoritative national survey of the carers' population in the UK. On this basis, it was estimated that there were 6 million carers in the United Kingdom at that time, of which $40 \%$ were male. Both statistics were a shock to the world of politics. However, the data were questioned by the researchers in the subsequent years. It was believed that the term 'care' used in the survey was not precise, and that a distinction should be made between informal care and informal assistance. Following this lead, it was finally concluded that there were 1.3-1.7 million informal carers in the country. In this way, researchers wanted to help politicians to identify the carers who needed practical support the most [22]. This study was a milestone in the fight for carers' rights, which has led to increased efforts in supporting carers.

\section{The Carers Act and the activities of Carers UK at the turn of the 21st century}

After the extension of Invalid Care Allowance, the formation of the Carers National Association and the impressive population survey from 1985, the general approach to carers changed. The question 'who provides care?' changed to 'who are the carers?' Meanwhile, the newly formed association, with the help of a member of the government, Malcolm Wicks, campaigned effectively in parliament [22]. Wicks was successful, and in 1995 the Carers (Recognition and Services) Act [26] entered the Book of Laws. According to this act, a carer is defined as a person who regularly provides or intends to provide care to a specific person [22].

The Carers Act was the first piece of legislation that gave carers the right to assess their needs, which was separate from the needs of those receiving care. This act was an important achievement, but due to the fact that local authorities did not allocate additional funds 
to implement the requirements of the new law, its value was more symbolic than real. The level of services for carers began to change only after 1997, with the election of a new government that committed itself to allocating adequate resources to informal family care [17]. The Carers Act was the main law for carers in the United Kingdom from 1995, being a summary of the efforts of individuals and institutions in the 20th century.

It is also worth adding that Wicks wanted to include all carers in the new law, but he had to start by identifying three specific groups, the most heavily burdened by caring responsibilities: adults caring for an older relative, carers of their own parents, and carers of their disabled children. Out of an initial 6 million carers in the UK, Wicks focused on 1.5 million people who cared for 20 hours or more per week; he called them the 'caring army' [27].

In the meantime, at the end of the 20th century, the Carers National Association evolved into a modern charity organisation developing services for carers. Many branches of the organisation focused their efforts on creating dozens of local care centres - many of them still provide the necessary support. In 1997, the organisation launched the first national helpline for carers and provided brochures and written information. The created services included projects to help carers return to work and to help former carers cope with grief. In 2001, the Carers National Association changed its name to Carers UK [19].

Timothy Cook, who was working with Carers UK for many years, in 2007 wrote a book The History of the Carers' Movement, in which he highlighted several factors that contributed to the organisation's success. Carers UK did not act alone, and over time, since the beginning of its existence, it has cooperated with over 40 other organisations. The campaigns, based mainly on studies and publicity, were another very important factor. The organisation focused on radio, local, and national newspapers, and later on television. It also cooperated with an agency that provided advice on advertising techniques [28]. They wanted to reach as many recipients as possible; they used strong titles that evoked emotions; they shared real stories of carers and, most importantly, used every opportunity for the carers to share their stories themselves; they put them at the heart of their activities [18].

Cook mentions one more key element that has contributed to the great success of not only Carers UK, but also the entire carers' movement. Since 1965, the organisation began to strongly engage politics in the social problem of family care and, what is important, remained politically neutral. Cook mentions that they have become a strong lobbying group, and the pressure was based mainly on research and figures, where the most important issue was the value that carers bring to the British state. In a radio interview in the late 1990s, the Prime Minister of the UK Tony Blair confirmed that family carers save the British state f76 billion a year [28].

Carers UK changed its image after the introduction of the Carers Act in 1997. Having served as an advocate for carers' rights and social responsibilities towards them, at the start of the 21 st century, they became an organisation monitoring social support. Carers UK is to date the largest charity supporting carers in the United Kingdom, conscious of its roots - a confederation formed from various groups and a key institution in the social movement that started in the second half of the 20th century.

\section{Conclusions - inspirations for actions promoting the issue of family carers in Poland}

The history of the carers' movement in the United Kingdom shows how long and difficult it has been to fight for the recognition and understanding of the challenges faced by family carers themselves, as well as social politics, in meeting the needs of an ageing population. Julia Twigg in her book from 1992 Carers: research and practice summarises the scale of changes in the late 20th century, saying that 10 years ago her book could not have been written, and 20 years ago no one would have even thought about such a subject of research. It is a measure of the changes that have taken place in family care in the last decades of the 20th century [29]. It started in the 1960s with press releases, campaigns, and the question 'who are the carers?'. The next step was to identify specific groups of people in need of support and cooperation between first supporting organisations, researchers, and politicians. The debate continued and developed through discussions about the role of social assistance, support groups, and the planned strategies for the future along with the creation of new rights for carers and monitoring their implementation.

Analysing the history of cultural and social changes as well as development of the family care movement in the UK, the question arises: what stage Poland is currently at in the context of family care? Knowledge of the historical background and similarities of the processes taking place in Poland and the United Kingdom allows us to place Poland in the point in history and indicate the next steps in the development of the national carers' movement.

The ageing of the population mentioned in the article and the demographic, social, and cultural 
changes that took place in the United Kingdom have not missed Poland. According to statistical data of the Central Statistical Office (GUS), in 1989-2014 the number of people aged 60 and more increased by about 2.9 million [30]. The processes observed in Poland indicate that since the 1990s the number of births and marriages has decreased and the number of divorces and informal relationships has increased [31].

It is also worth noting that palliative hospice care is very well developed in Poland, as it is in the UK. According to the Atlas Europa study of 2019, Poland is one of the first countries in Eastern Europe to introduce a system of national palliative care services, and it is the second country in Europe, following the United Kingdom, with the highest number of such services [32].

Focusing on the problem of family care itself, in Poland the most extensive activity in this area has been carried out by the Hospice Foundation from Gdańsk, which for several years has been successfully conducting social campaigns on the topic of informal care and holding a special day for carers - Carer's Day [33]. The Foundation was also one of the patrons of the first public survey on family carers in Poland in 2016, with over 1000 respondents involved [34]. They produced an Internet guide for family carers, which contains valuable information and practical support [35]. As part of the annual nationwide campaign called 'A hospice is a life, too' starting in 2016 the Foundation began to draw attention to the problems of informal care. Since then, the Foundation has conducted three campaigns under the names "Family carer - a lonely hero?" and "Family carer - does not have to be alone", which were aimed at broadening social awareness and practical support of caregivers. Workshops and educational meetings for caregivers were organised and the focus was on the development of local volunteering activities. The attention of the ombudsman was drawn to the matter of caregivers who intervened in a letter to the Minister of Labour, Family, and Social Policy, funding was obtained for the training for caregivers, and the construction of a respite care centre in Gdańsk began [33]. Since 2019, the term "respite care" has been officially included in the government's activities through an official letter, and this form of assistance is legally granted to the first group of family carers. Parents of severely ill and disabled children can apply for funds [36]. It is also worth mentioning the national educational program "Damy Radę", implemented by the foundation Razem Zmieniamy Świat from Toruń. As part of the project, the foundation created an Internet guide for family carers, organises free workshops, provides free manuals, and prepares instructional videos [37]. In 2019, on the initiative of eight patient organisations, the
National Day of Carers was established, which is to be celebrated on the 12th of February each year [38].

The above brief comparison of demographic and cultural changes, the level of development of end-of-life care and the formation of organisations supporting family carers allows us to state that Poland is currently at the stage where the UK was in the 1980s. Despite the actions already taken, we are still at the beginning of a journey to include family carers in the integrated care system. An urgent problem to be solved in Poland is the integration of social welfare activities with medical care, including voluntary work and support of family carers, which has been suggested for years by researchers of the topic [39]. Poland must find an answer to the problem of the growing population of elderly and dependent people, and this issue is still at an early stage in the social discourse. Therefore, subsequent actions could be modelled on good practices developed by Carers UK, which have been successfully implemented in British society. The beginnings, development, and reorganisation in the structures of the Carers UK, the impact of these changes on government representatives and researchers, as well as their efforts to support carers in the UK can be a proposal for further steps to be taken in Poland. The activities of organisations supporting family carers in the UK and the latest initiatives of the movement in the 21 st century will be presented in another essay, prepared by the author for Polish readers, showing the current challenges and ways to respond to them.

\section{Conflict of interests}

Author declare no conflict of interest.

Funding

This study has no funding.

\section{References}

1. carersuk.org [Internet]. Carers UK; 2019. https://www. carersuk.org/news-and-campaigns/news/research-morethan-600-people-quit-work-to-look-after-older-and-disabled-relatives-every-day (2019 February 20).

2. carers.org [Internet] Carers UK. Juggling work and unpaid care. A growing issue, London; 2019. http://www. carersuk. org/images/News_and_campaigns/Juggling_work_and_ unpaid_care_report_final_WEB.pdf (2019 March 5).

3. Janowicz A. Opiekunowie rodzinni. Wyzwania i możliwoścrcia. CeDeWu, Warszawa 2019.

4. Glendinning $\mathrm{C}, \mathrm{Ig} \mid \mathrm{G}$. Long-term Care in Germany and the UK. In: Walker A, Naegele G. ed. Social Policy in Ageing Societies: Britain and Germany Compared. Palgrave Macmillan, Basingstoke 2009.

5. Hicks C. Who cares. Looking after people at home. Virago, London 1988.

6. Janowicz A. Rola opiekunów nieformalnych w opiece u kresu życia. Przyczynek do badań w ramach projektu European Palliative Care Academy (EUPCA). In: Prace Poglądowe. Piel. Zdr. Publ. 2014; 4(2): 161-167. 
7. Janiszewska A. Zróżnicowanie przestrzenne starzenia się ludności na świecie. Acta Universitatis Lodziensis. Folia Oeconomica. 2018; 5(331): 91-113, doi: 10.18778/02086018.331.06.

8. Ośrodek Informacji ONZ w Warszawie: Działania ONZ w kwestii starzenia się społeczeństw; 2019. http://www. unic.un.org. pl/ageing/dzialania.php (2019 February 19).

9. Parker G. With due care and attention a review of research on informal care. Family Policy Studies Centre, London 1985.

10. Office for National Statistics: Childbearing for Women Born in Different Years, England and Wales: 2014; 2015. https:// www.ons.gov.uk/peoplepopulationandcommunity/birthsdeathsandmarriages/conceptionandfertilityrates/bulletins/childbearingforwomenbornindifferentyearsenglandandwales/2015-11-10 (2019 April 3).

11. Office for National Statistics: Future of an ageing population; 2016. https://www.gov.uk/government/publications/future-of-an-ageing-population (2019 February 17).

12. Reichert M, Phillips J. The Changing Generational Contract Within and Outside the Family: Britain and Germany Compared. In: Walker A, Naegele G. ed. Social Policy in Ageing Societies: Britain and Germany Compared. Palgrave Macmillan, Basingstoke 2009.

13. Davis A. Modern Motherhood: Women and Family in England, c. 1945-2000. Manchester University Press, Manchester 2012.

14. Office for National Statistics: Full report - Women in the labour market; 2013. http://webarchive.nationalarchives.gov.uk/20160105160709/http://www.ons.gov. uk/ons/dcp171776 328352.pdf (2019 April 6).

15. Cook $\mathrm{H}$. The long sexual revolution. English women, sex, and contraception 1800-1975. Oxford University Press, Oxford 2004.

16. Janowicz A, Krakowiak P, Stolarczyk A. In Solidarity. Hospice-Palliative Care in Poland. Biblioteka Fundacji Hospicyjnej, Gdańsk 2015.

17. Cavaye J. Hidden Carers. Dunedin Academic Press, Edinburgh 2006.

18. Carers and Human Rights: History of the Carers Movement UK [video]; 2015. https://carersandhumanrights. wordpress. com/history-of-the-carers-movement-uk/ (2019 March 25).

19. Carers UK; 2019. https://www.carersuk.org/about-us/who-we-are/our-history (2019 March 7).

20. Glendinning C. Dependency and interdependency: the incomes of informal carers and the impact of social security. In: Baldwin S, Parker G, Walker R. ed. Social Security and Community Care. Aldershot 1988.

21. Baldwin S. The need for care in later life: social protection of older people and family caregivers. In: Baldwin S, Falkingham J. ed. Social Security and Social Change: new challenges to the Beveridge model. Harvester Wheatsheaf, London 1994.
22. Bytheway B, Johnson J. The social construction of 'carers'. In: Symonds A, Kelly A. ed. The Social Construction of Community Care. Palgrave, London 1998.

23. Equal Opportunities Commission. The Experience of Caring for Elderly and Handicapped Dependents. Manchester 1980.

24. Department of Health and Social Security, Scottish Office, Welsh Office, Northern Ireland Office. Growing older, London 1981.

25. Green H. Informal carers: a study carried out on behalf of the Department of Health and Social Security as part of the 1985 General Household Survey. London 1988.

26. Carers (Recognition and Services) Act 1995. https://www. legislation.gov.uk/ukpga/1995/12/contents (2019 July 5).

27. House of Commons. Carers (Recognition and Services) Bill. Parliamentary Papers, London 1995.

28. Institute of Historical Research: The History of the Carers' Movement: A Remarkably Successful Story. Why?. [Podcast]; 2009. https://blog.history.ac.uk/2009/10/history-of-the-carers-movement/ (2019 March 5).

29. Twigg J. Carers: research and practice. HMSO, London 1992.

30. Glówny Urząd Statystyczny: Ludność w wieku 60+. Struktura demograficzna i zdrowie; 2016. https://stat.gov. $\mathrm{pl} /$ obszary-tematyczne/ludnosc/ludnosc/ludnosc-w-wieku-60-struktura-demograficzna-i-zdrowie, 24,1.html (2019 May 24).

31. Radziwinowiczówna A, Rosińska A, Kloc-Nowak W. Ethnomorality of Care. Migrants and their Aging Parents. Routledge, London 2018.

32. Atlas of Palliative Care in Europe 2019. http://dadun.unav. edu/handle/10171/56787 (2020 January 26).

33. Gdańsk: Fundacja Hospicyjna; 2019. http://www.fundacjahospicyjna.pl/pl/o-nas/edukacja-spoleczna/kampanie-spoleczne (2019 July 20).

34. Gdańsk: Fundacja Hospicyjna; Fundacja Agory; 2019. http:// www.hospicja.pl/images/pdf/wyniki_OP.pdf (2019 August 15).

35. Hospicjum to też życie. Przewodnik dla opiekunów rodzinnych; 2019. http://www.opiekunrodzinny.pl (2019 August 15).

36. Dolnośląski Urząd Wojewódzki we Wrocławiu. Opieka wytchnieniowa - edycja 2019. https://www.duw. $\mathrm{pl} / \mathrm{pl} /$ urzad/programy/solidarnosciowy-fundusz/opieka-wytchnieniowa/15539, Opieka-wytchnieniowa-edycja-2019. html (2019 November 20).

37. Damy Radę. https://damy-rade.info/ (2020 February 1).

38. Deklaracja ustanowienia Ogólnopolskiego Dnia Opiekuna; 2019. http://www.gazetasenior.pl/wp-content/uploads/2018/12/deklaracja_organizacji_pacjenckich_ogolnopolski_dzien_opiekuna.pdf (2019 August 20).

39. Krakowiak P. Wolontariat $w$ opiece $u$ kresu życia. Wydawnictwo Naukowe Uniwersytetu Mikołaja Kopernika, Toruń 2012. 


\section{Geneza i rozwój ruchu opiekunów rodzinnych w Wielkiej Brytanii w XX wieku}

Artykuł jest tłumaczeniem pracy: Klimek M. Origin and development of the family carers' movement in the United Kingdom in the 20th century. Palliat. Med. Pract. 2020 tom 14, nr 1: 26-34.

Należy cytować wersję pierwotną.

Piśmiennictwo znajduje się na stronach 33-34.

\section{Streszczenie}

Historia ruchu opiekunów rodzinnych w Wielkiej Brytanii swój początek miała w drugiej połowie XX wieku. Przemiany demograficzne, społeczne i kulturowe w Zjednoczonym Królestwie sprawiły, że w kontekście potrzeb starzejącego się społeczeństwa konieczne było zdefiniowanie roli opiekuna rodzinnego. Organizacja Carers UK wraz z przedstawicielami rządu i badaczami walczyła o rozpoznanie i zrozumienie wyzwań, przed którymi stają opiekunowie, o uznanie praw dla opiekunów oraz przyjęcie i rozpowszechnienie terminu „opiekun” (carer) w świadomości społecznej. Głównym celem opracowania jest ukazanie genezy powstania ruchu opiekunów rodzinnych w Wielkiej Brytanii w XX wieku oraz procesu integracji różnych podmiotów wspierających opiekunów. Przedstawione działania mogą być inspiracją dla Polski i innych krajów, stających przed podobnymi wyzwaniami opieki rodzinnej nad osobami niesamodzielnymi ze względu na chorobę lub wiek.

Palliat Med Pract 2020; 14, 1: 35-43

Słowa kluczowe: opiekun rodzinny, opieka nieformalna, Carers UK, starzenie się społeczeństwa, opieka paliatywna, wolontariat

\section{Wstęp}

W lutym 2019 roku największe serwisy informacyjne w Wielkiej Brytanii podały do wiadomości informację, że w kraju ponad 600 osób każdego dnia rezygnuje $z$ pracy, by opiekować się starszymi i niepełnosprawnymi bliskimi [1]. Dane te były wynikiem badań przeprowadzonych na przełomie 2018 i 2019 roku przez organizację Carers UK. Wykazały one, że w 2019 roku szacowana liczba osób, które zrezygnowały z pracy, aby rozpocząć opiekę nad członkami rodziny to 2,6 miliona, a prawie pół miliona $z$ nich zdecydowało się na ten krok w ostatnich dwóch latach [2]. Liczby te ukazują skalę zjawiska, prowokując medialnie i zwracając uwagę na wyzwania cywilizacyjne naszych czasów.

Definicje opiekuna rodzinnego i opiekuna nieformalnego przyjęte $w$ niniejszym artykule określają opiekuna jako „członka rodziny, który nieodpłatne opiekuje się bliską osobą z rodziny, niesamodzielną ze względu

\footnotetext{
Adres do korespondencji:

Martyna Klimek

Fort Community Centre, Health and Social Care

25 North Fort Street

EH6 4HF Edinburgh, Wielka Brytania

e-mail:martynaklimek@gmail.com
} 
na chorobę czy niedołężność w sposób regularny i trwały, w znacznym tygodniowym wymiarze godzin. Wspiera go emocjonalnie, pomaga w zakresie czynności dnia codziennego, czynności higieniczno-pielęgnacyjnych, w zależności od potrzeb podopiecznego. Terminem „opiekun nieformalny” określa się osobę dorosłą, której z zależnym od niej podopiecznym nie łączą więzi rodzinne [3]. W literaturze przedmiotu określenia te rozróżnia się na podstawie więzi rodzinnych. Jednak terminy te $w$ drugiej połowie $X X$ wieku w Wielkiej Brytanii były używane zamiennie i odnosity się głównie do opieki rodzinnej. Działo się tak z uwagi na bardzo małą znajomość tematu i na to, że samo słowo „opiekun" (carer) było pojęciem nowym, o czym szerzej w kolejnej części pracy. Definicje te będą używanie zamiennie również $w$ tym artykule.

Zjednoczone Królestwo w wyniku licznych przemian społeczno-kulturowych XX wieku od wielu lat zmaga się z konsekwencjami starzenia się społeczeństwa, w tym ze wzrostem populacji i wieku opiekunów rodzinnych. Niezwykle ważne i ciekawe jest to, że temat opieki rodzinnej jest powszechnie znany w społeczeństwie brytyjskim i od wielu lat badany. Caroline Glendinning i Gerhard Igl w opracowaniu z 2009 roku Long-term Care in Germany and the UK podkreślają, że Wielka Brytania jest jednym z niewielu krajów, w których opiekunowie zamiast wsparcia otrzymywanego pośrednio poprzez zasiłek dla podopiecznego, mają bezpośrednie prawa do różnego rodzaju świadczeń, głównie finansowych [4]. Jest to efekt działań organizacji wspierających opiekunów, badaczy i polityków, którzy w XX wieku stopniowo przekształcili prywatną kwestię opieki rodzinnej w problem natury społecznej, tworząc system wsparcia integrującego różne podmioty sprawujące opiekę.

Kraj ten przeszedł długą i trudną drogę w walce o prawa dla opiekunów i budowanie świadomości społecznej. Pomimo tego, że ruch opiekunów rodzinnych w Wielkiej Brytanii swoją historię rozpoczyna już w latach 60. XX wieku, to po ponad 20 latach od założenia pierwszej organizacji wspomagającej opiekunów wiele kluczowych pytań w dalszym ciągu pozostawało bez odpowiedzi. W 1988 roku Cherrill Hicks w przejmującym wstępie do swojej książki Who cares. Looking after people at home, zwracając uwagę na rosnącą grupę opiekunów, podsumował stan wiedzy społecznej i politycznej w odniesieniu do opiekunów rodzinnych: „W Wielkiej Brytanii rośnie grupa ludzi, głównie kobiet, które trafnie zostały opisane jako zapomniana armia. Są opiekunami — ponad milion kobiet i mężczyzn — którzy poświęcili większość swojego życia, aby opiekować się niepełnosprawnymi i starszymi osobami od nich zależnymi. Co wiemy o opiekunach? Bardzo mało. Wiemy, że obecnie około 1,3 miliona osób pełnoetatowo opiekuje się osobami starszymi lub niepełnosprawnymi, a dla 5 lub 6 milionów opieka jest głównym obowiązkiem. Wiemy, że większość z nich — trzy na cztery osoby - to kobiety, zazwyczaj córki, żony i matki swoich podopiecznych. Wiemy, że w większości rodzin to zazwyczaj jedna osoba przyjmuje pracę opiekuna, przy niewielkim lub żadnym wsparciu ze strony innych członków rodziny, przyjaciół, sąsiadów lub usług. (...) Wiemy, że opieka jest długoterminowym zobowiązaniem, które można zmierzyć w latach, a nie w miesiącach. (...) Wiemy, że utrzymując swoich krewnych poza instytucjami, opiekunowie oszczędzają państwu brytyjskiemu ponad 11 miliardów funtów rocznie. Zawsze istniały osoby, głównie kobiety, które poświęcały się dla opieki nad niepełnosprawnymi rodzicami lub dziećmi, jednak w przeszłości rola ta została przyjęta jako przedłużenie normalnych obowiązków kobiet, jako naturalna ofiara wzięta z miłości i obowiązku. Dopiero w ciągu ostatnich kilku lat ci ludzie otrzymali niemal oficjalny tytuł - opiekun — a rząd zaczął poważnie traktować ich potrzeby. Dlaczego? Ponieważ opieka jest w kryzysie, a opiekunowie mówią, że nie mogą już sobie poradzić" [5].

Analizując powstanie i rozwój ruchu opiekunów rodzinnych w Wielkiej Brytanii, można znaleźć inspiracje i podpowiedzi dla tworzących się w Polsce inicjatyw obywatelskich oraz społecznych, dotyczących zagadnienia opieki rodzinnej nad osobami niesamodzielnymi, przewlekle chorymi i znajdującymi się u kresu życia. Zapoznanie się z przemianami społeczno-demograficznymi oraz tłem historycznym rozwoju tego ruchu w Wielkiej Brytanii pomóc może w zrozumieniu etapu, na którym obecnie znajduje się Polska w kontekście opieki rodzinnej. Problem opieki rodzinnej w Polsce został zauważony, ale jak wskazuje Anna Janowicz, prezes Fundacji Hospicyjnej i inicjatorka licznych działań na rzecz osób zależnych i ich opiekunów, „w Polsce brakuje całościowych i zadowalających informacji na temat opieki nieformalnej nad osobami u kresu życia" [6]. Działania społeczne i polityczne od dziesięcioleci prowadzone w Wielkiej Brytanii mogą być inspiracją zarówno dla osób tworzących politykę społeczną w Polsce, jak i dla organizacji pozarządowych wspierających opiekunów rodzinnych. Dobre praktyki zaczerpnięte z Wysp Brytyjskich mogą wesprzeć samych opiekunów, których wysiłki powinny być uznane i wspierane zarówno przez systemy opieki, jak i przez społeczności lokalne.

\section{Czynniki społeczno-kulturowe a populacja opiekunów w Wielkiej Brytanii}

Ważną częścią historii, niezbędną dla zrozumienia przyczyn wzrostu populacji osób niesamodzielnych 
oraz ich opiekunów w Wielkiej Brytanii, są czynniki demograficzne, społeczne i kulturowe. W literaturze i opracowaniach dotyczących opieki nad osobami niesamodzielnymi jako główny czynnik wpływający na obecne wyzwania wskazuje się przede wszystkim procesy starzenia się społeczeństwa.

Starzenie się ludności jest tematem obecnym w międzynarodowym zarówno dyskursie społecznym, jak i w przestrzeni nauk społecznych: psychologii, pedagogice i pracy socjalnej, będąc również przedmiotem badań socjologicznych. Starzenie się społeczeństw nie jest zjawiskiem nowym, ale stało się ono powszechnym problemem od drugiej połowy XX wieku. W 1982 roku w Wiedniu odbyło się Pierwsze Światowe Zgromadzenie na temat Starzenia się Społeczeństw [7]. W krótkim podsumowaniu, udostępnionym przez Ośrodek Informacji ONZ w Warszawie, zawarte zostały najważniejsze przesłania z tego spotkania: „podczas obrad podkreślano, że zjawisko starzenia się społeczeństw (...) uderza najbardziej dotkliwie w społeczeństwa rozwijające się oraz te znajdujące się w okresie transformacji. Wiąże się to z poważnymi skutkami społecznymi, ekonomicznymi i kulturowymi. Zauważono, że wiele państw nie ma opracowanych programów uwzględniających potrzeby szybko rosnącej populacji ludzi starszych. Stwierdzono konieczność zapewnienia starszym osobom uczestnictwa w życiu społecznym i rodzinnym, samorealizacji, odpowiedniego poziomu życia. Powyższe postulaty zawarte zostały w Międzynarodowym Planie Działania w Kwestii Starzenia Się Społeczeństw opracowanym przez przedstawicieli 250 organizacji i 121 narodów" [8].

W drugiej połowie XX wieku największy odsetek ludzi w wieku powyżej 65 lat mieszkał na kontynencie północnoamerykańskim (8,2\%) i europejskim (8\%). Dopiero od połowy lat 60. to Europa stanęła na pierwszym miejscu demograficznej starości, sięgając 10\%. Dynamika wzrostu odsetka ludzi starszych na świecie zaczęła intensyfikować się od 1990 roku — wówczas $6,2 \%$ całej populacji świata to ludzie w podeszłym wieku. Odsetek ludności starszej nadal największy był w Europie i wynosił 13,5\% [7]. Przedstawione w skrócie dane statystyczne ukazują dynamikę zmian demograficznych dotykających szczególnie społeczeństwa europejskie. Konsekwencjami tych zmian są rosnąca liczba osób niesamodzielnych i starszych w domach, ale także ich opiekunów rodzinnych.

Wielka Brytania mocno odczuła wzrost populacji osób starszych. W 1901 roku około 0,8 miliona mężczyzn i milion kobiet było w wieku 65 lat i więcej. W 1981 roku liczby te wzrosły do 3,3 miliona mężczyzn i 5,1 miliona kobiet [9].

Jedną z przyczyn starzenia się społeczeństwa, jak również czynnikiem bezpośrednio wpływającym na problemy z opieką rodzinną nad osobami niesamodzielnymi jest spadek liczby urodzeń, wiążący się ze zwiększającą się bezdzietnością. Odsetek kobiet bezdzietnych w Zjednoczonym Królestwie wzrósł z $11 \%$ wśród urodzonych w 1942 roku do $18 \%$ dla osób urodzonych w 1969 roku [10]. Już w 1985 roku Gillian Parker zauważyła, że wielkość rodziny systematycznie spada, podczas gdy liczba bezdzietnych małżeństw wzrasta, co będzie miało duży wpływ na potencjalną populację opiekunów: więcej starszych par nie będzie miało bezpośredniego krewnego, który mógłby się nimi zająć lub mniej dorosłych dzieci będzie dzielić opiekę nad starszymi rodzicami [9].

W literaturze dotyczącej wyzwań opieki nieformalnej w Wielkiej Brytanii duży nacisk kładzie się na zmiany w strukturze rodziny, które w znaczący sposób wpływają na wagę problemów w zapewnieniu opieki osobom niesamodzielnym. W ostatnich dziesięcioleciach XX wieku Wielka Brytania, podobnie jak wiele krajów rozwijających się, była świadkiem ewoluującego schematu zmian w strukturze rodziny, jej rolach i relacjach. Postawy ludzi w stosunku do małżeństwa, konkubinatu, samotnego rodzicielstwa, rozwodów i bezdzietności zmieniły się. Małżeństwo, mimo że nadal uważane za dominującą formą rodziny, przestało być uznawane za jedyne ramy, w których można żyć jako rodzina i mieć dzieci [11]. Nastąpił też istotny spadek trwałości i jednorodności długoterminowych relacji między parami. Coraz bardziej powszechne stały się związki partnerskie bez ślubu i rodzenie dzieci poza związkiem. Same związki natomiast — niezależnie od tego, czy w małżeństwie, czy w związku partnerskim - mniej stabilne [11].

Zmiany struktur rodzinnych doprowadziły do pojawienia się nowych zagrożeń społecznych związanych ze starzeniem się społeczeństwa, a jednym z nich jest sprostanie rosnącemu zapotrzebowaniu na bezpłatną opiekę. Monika Reichert i Judith Phillips w swojej pracy z 2009 roku The changing generational contract within and outside the family: Britain and Germany compared zwracają uwagę na to, że rodziny niekoniecznie są już grupą ludzi połączonych ze sobą biologicznie, stają się one coraz bardziej złożone. Zmiany w zachowaniu, postawach i stylu życia ludzi w XX wieku pozostawiły konsekwencje dla rodzin i relacji międzypokoleniowych. Autorki wskazują przede wszystkim na rosnącą liczbę osób, które mieszkają same przez całe swoje życie; większą liczbę par, które nigdy nie były w małżeństwie lub nie mają dzieci; rosnącą liczbę rozwodów i ponownych małżeństw; zwiększony udział kobiet na rynku pracy oraz rosnącą liczbę członków rodziny żyjących w dalekich odległościach od siebie [12]. Gillian Parker w 1985 roku, analizując zmiany w strukturze rodziny zauważyła, że jednym ze znaczących czynników, które mogą wpłynąć na potencjalną pulę 
opiekunów, jest wzrost liczby rozwodów i ponownych małżeństw. W 1961 roku liczba osób rozwodzących się na 1000 par małżeńskich wynosiła 2,1, a w 1980 roku wzrosła aż do 12 . Jednym z rezultatów ponownego wyboru partnerów małżeńskich może być zatarcie linii odpowiedzialności za opiekę nad rodzicami i teściami [9]. W kontekście zmian struktur rodzinnych warto wspomnieć, że w kraju tym nastąpił również wzrost liczby gospodarstw domowych samotnych rodziców. W 1961 roku samotnych rodziców z co najmniej jednym, zależnym od niego dzieckiem było 367 tysięcy, w 1971 roku było ich już 515 tysięcy [9].

Analizując historię przemian historycznych i społecznych Wielkiej Brytanii w XX wieku w odniesieniu do opieki rodzinnej, zauważyć można, że kluczowym czynnikiem zmian jest ewolucja roli kobiety $w$ rodzinie i społeczeństwie po II wojnie światowej. W latach powojennych zakładano, że kobiety są naturalnymi opiekunami i że wszyscy opiekunowie rodzinni to kobiety. Postrzeganie kobiet jako opiekunek było jedną z podstaw państwa opiekuńczego, które następowato po wizji mężczyzny - żywiciela rodziny i modelu gospodyni domowej [13]. Gillian Parker w 1985 roku pisała, że politycy, którzy nie mają świadomości lub ignorują przemiany zachodzące w kraju są narażeni na duże ryzyko tworzenia nieodpowiednich ustaw $i$ usług. Przywołała przykład oczekiwań dotyczących życia kobiet w powojennej Wielkiej Brytanii — zakładano wówczas, że samotna kobieta, mimo że odsetek ludzi samotnych w populacji tego kraju przez ostatnie 50 lat zmniejszał się, będzie nadal dostępna do opieki nad osobami w podeszłym wieku. Powojenne ustawodawstwo dotyczące zabezpieczenia społecznego zakładało, że większość kobiet będzie zamężna i tym samym zależna finansowo od swoich mężów. W ten sposób błędnie oceniono skalę problemu, zarówno w przypadku udziału kobiet w rynku pracy, jak i wzrastającej liczby rozwodów [9].

Masowe wejście kobiet na rynek pracy spowodowało zmianę standardowego podziału pracy w rodzinach. Praca w domu, w opiece nad dziećmi i osobami starszymi, która wcześniej była wykonywana bezpłatnie przez kobiety, musiała być zapewniona z zewnątrz - odpłatnie lub poprzez przyznane świadczenia. Mimo że mężczyźni zaczęli odgrywać coraz większą rolę w sprawowaniu opieki, to tam, gdzie nie było odpowiednich formalnych świadczeń, od kobiet zazwyczaj nadal oczekiwało się, że będą sprawowały rolę opiekunek [11]. Dla porównania, w 1961 roku zamężne kobiety stanowiły około $16 \%$ całkowitej siły roboczej, w 1981 roku oczekiwano, że będą stanowić $25 \%$ całości [9]. Z badań Narodowego Urzędu Statystycznego (Office of National Statistics) wynika, że zatrudnienie kobiet wzrosło z 53\% w 1971 roku do 67\% w 2013 roku [14].
Powyższe przemiany społeczne były pośrednio efektem rewolucji seksualnej XX wieku. Pomiędzy 1955 a 1975 rokiem rząd brytyjski zaczął angażować się w kontrolę wzrostu populacji, aby ostatecznie zapewnić antykoncepcję wszystkim kobietom i mężczyznom, niezależnie od wieku i stanu cywilnego [15]. Tabletka antykoncepcyjna wprowadzona w 1961 roku, możliwość kontroli potencjalnej ciąży i zmiana postaw wobec seksualności dotychczas funkcjonującej głównie w ramach małżeństwa wpłynęły na obniżenie poziomu dzietności, małżeństwo zaczęto postrzegać jako jedną z możliwych opcji, a dotychczas funkcjonująca definicja rodziny zaczęła być coraz bardziej płynna [15].

Zaprezentowane analizy pomagają $w$ zrozumieniu zmian demograficznych, jakie zaszły w Wielkiej Brytanii oraz wyzwań i trudności polityki społecznej w sprostaniu wymaganiom starzejącej się populacji. Wzrost liczby osób starszych i spadek liczby potencjalnych opiekunów wiązał się z większym zapotrzebowaniem na opiekę, a obowiązek ten spadał przede wszystkim na opiekunów rodzinnych. W kontekście tym nie należy jednak zapominać o kwestii wsparcia ze strony szpitali i placówek opiekuńczych, które były i są jedną z odpowiedzi na problemy opieki rodzinnej.

Warto wspomnieć, że jedną z form tego rodzaju wsparcia jest opieka paliatywno-hospicyjna, która swoje początki miała właśnie w Wielkiej Brytanii w XX wieku. Dążąc do edukacji społecznej w odniesieniu do osób nieuleczalnie chorych oraz zapewnienia właściwej opieki pacjentom w stanie terminalnym, profesjonalną opiekę medyczną i pielęgniarską połączono $\mathrm{z}$ troską o potrzeby pozamedyczne pacjentów $\mathrm{i}$ ich rodzin oraz szkolenia zespołowe [16]. Były to pierwsze udane próby włączenia rodzin do zintegrowanej opieki nad osobami niesamodzielnymi.

Wzrost popularności placówek opiekuńczych $z$ pewnością był $w$ jakimś stopniu odpowiedzią na zmiany demograficzne, które zaszły w Wielkiej Brytanii, ale procesy starzejącego się społeczeństwa, zmiany struktury rodziny, spadek płodności i ewolucja roli kobiety przyczyniły się do przemian społecznych, w wyniku których konieczne było zdefiniowanie roli opiekuna rodzinnego. Dotychczasowe założenie, że to kobieta jest naturalnym opiekunem zaczęto uznawać za błędne, a temat opieki rodzinnej z kwestii prywatnej przekształcił się w problem natury społecznej.

\section{Piervwsze organizacje wspierające, budowanie świadomości społecznej i walka o prawa dla opiekunów w Wielkiej Brytanii}

Joyce Cavaye w swojej książce Hidden Carers [17] zwraca uwagę na to, że rola opiekunów rodzin- 
nych w dzisiejszym rozumieniu stała się zauważalna w wyniku dwóch powiązanych ze sobą elementów. Pierwszym z nich są badania i opracowania, którymi zajmowali się politycy i badacze społeczni, drugim czynnikiem natomiast są grupy nacisku, które według Cavaye odegrały kluczową rolę w budowani świadomości społecznej i politycznej [17]. Organizacja Carers UK była pierwszą organizacją charytatywną, która od początku lat 60. walczyła o prawa i uznanie opiekunów rodzinnych. Dzisiaj, po ponad 50 latach działalności, nadal jest to największa organizacja wspierająca opiekunów i warto cofnąć się do początków jej powstania aby zrozumieć jak długą drogę przeszła w walce o zmianę jakości życia opiekunów.

W 1963 roku pastor Mary Webster napisała list do lokalnej gazety o trudnościach związanych z pracą i opieką nad starzejącymi się rodzicami. W 1954 roku, w wieku 31 lat, zrezygnowała z pracy, aby zająć się swoimi rodzicami. Po prawie 10 latach podzieliła się swoją historią, z sukcesem nagłaśniając trudne doświadczenia kobiet-opiekunek, które zmagały się nie tylko z trudnościami finansowymi, lecz także z izolacją. Pojawiły się wówczas kolejne artykuły: autorstwa May Abbott w „The Guardian" w 1963 roku Samotne i Milczące (Single and Silent) oraz autorstwa Rosmery Small Samotne - ale nie bez obowiązków (Single - but they certainly not carefree) i wiele innych z podobnym, emocjonalnym przesłaniem [18]. Były to pierwsze ruchy budujące świadomość społeczną związaną z osobami sprawującymi opiekę, jeszcze wtedy skupione tylko na kobietach.

W 1965 roku Webster założyła organizację Krajowa Rada dla Samotnej Kobiety i Osób Od Niej Zależnych (NCSWD, National Council for the Single Woman and Her Dependents) [19]. Organizacja ta od samego początku nastawiona była na bezpośrednią współpracę z opiekunami i chciała dowiedzieć się o nich jak najwięcej. Już same efekty po publikacji artykułu z 1963 roku upewniły Webster w przekonaniu, że temat opieki rodzinnej jest wielkim problemem społecznym, który warto nagłośnić - otrzymała ona wówczas setki listów od kobiet w podobnej sytuacji życiowej, które poświęcały swoje życie dla opieki nad innymi. Krótko po założeniu organizacji NCSWD przeprowadziło pierwsze badanie, w którym udział wzięło aż 700 opiekunek [18]. Przez kolejne lata organizacja prowadziła kampanie oraz współpracowała z politykami o rozszerzanie istniejących oraz tworzenie nowych praw dla opiekunów.

Znaczącym osiągnięciem wszystkich osób i organizacji działających w tamtym czasie była kampania i wprowadzenie w 1976 roku zasiłku opiekuńczego (Invalid Care Allowance). Miało to na celu ochronę bieżących dochodów i przyszłych świadczeń emery- talnych uczestników rynku pracy, których zatrudnienie w pełnym wymiarze godzin zostało przedwcześnie zakończone z uwagi na sprawowanie opieki nad starszymi krewnymi [20]. Prawdopodobnie był to pierwszy znaczący gest rządu centralnego wobec osób świadczących opiekę. Skupiając się jednak na problemach finansowych związanych z odejściem z pracy, świadczenie nie przysługiwało kobietom zamężnym - zakładano wówczas, że kobiety w związkach małżeńskich nie pracują i pozostają w domach [21].

W 1981 roku utworzyła się kolejna organizacja - Stowarzyszenie Opiekunów (Association of Carers). Stowarzyszenie założone zostało przez Judith Oliver, która sama opiekowała się niepełnosprawnym mężem. Uważała, że istnieje potrzeba organizacji, która wspierałaby wszystkich opiekunów, a nie tylko osoby opiekujące się osobami starszymi [19]. Stowarzyszenie Opiekunów zaczęło walczyć o rozszerzenie zasiłku opiekuńczego o kobiety zamężne, określając opiekuna jako każdego, kto prowadzi ograniczone życie ze względu na sprawowanie opieki nad osobą upośledzoną umysłowo lub fizycznie oraz osobą niesamodzielną ze względu na zaawansowany wiek. Celem organizacji było także zwrócenie uwagi na potrzeby opiekunów, które są tak samo ważne, jak potrzeby osób, którymi się opiekują [22]. W międzyczasie NCSWD zmieniła swoją nazwę na Krajową Radę Opiekunów i Ich Starszych Podopiecznych (National Council for Carers and Their Elderly Dependands). Organizacje te przez kilka lat rywalizowały ze sobą, jednak w 1986 roku połączyły się, tworząc Krajowe Stowarzyszenie Opiekunów (Carers National Association) [22]. Warto dodać, że nazwa Carers National Association tłumaczona z języka angielskiego, słowo „opiekun" stawia na pierwszym miejscu. Był to celowy zabieg organizacji, która również przez samą nazwę chciała pokazać jak duże znaczenie nadaje pracy na rzecz opiekunów, symbolicznie stawiając ich na pierwszym miejscu [18]. Nowa organizacja stała się silną grupą nacisku i odegrała zasadniczą rolę w wprowadzeniu zmian w ustawodawstwie dla opiekunów w Wielkiej Brytanii [17].

\section{Opiekun rodzinny w Wielkiej Brytanii — dostrzeżenie zmiany roli kobiety $\mathrm{i}$ kształtowanie się definicji}

Kampania na rzecz rozszerzenia zasiłku opiekuńczego dla kobiet zamężnych, prowadzona przez Stowarzyszenie Opiekunów w 1981 roku, zwróciła uwagę na kwestie końca pełnienia opieki. W rezultacie przyjmowane przez lata założenie, że kobiety naturalnie i dobrowolnie świadczą opiekę rodzinną zaczęło być poważnie kwestionowane. W szczególności zwrócono 
uwagę na to, w jaki sposób te oczekiwania uniemożliwiły kobietom $\mathrm{w}$ średnim wieku powrót do płatnego zatrudnienia po zakończeniu opieki. W odpowiedzi na tę obawę pozarządowa organizacja promująca równość płci (Equal Opportunity Commission) przedstawiła pierwszą wiarygodną ocenę nieodpłatnego i nieuznanego wkładu kobiet w opiekę nieformalną [22]. Komisja przyznała, że jest oczekiwane, iż to właśnie rodziny będą zapewniały opiekę dla ogromnej większości osób niepełnosprawnych, chorych i starszych. Obowiązek ten zazwyczaj spada na kobietę, która jest najbliżej powiązana z osobą wymagającą opieki [23].

Zmiana roli kobiety $w$ rodzinie i społeczeństwie była fundamentalnym elementem dla utworzenia się ruchu opiekunów, a w efekcie dyskusją nad samą definicją słowa "opiekun". Bill Bytheway i Julia Johnson w opracowaniu z 1998 roku The social construction of carers zauważają, że mniej niż 40 lat temu samo słowo „opiekun” było ledwie znane w języku angielskim. Było ono szczególnie trudne do zrozumienia dla tych, którzy uważali siebie za opiekunów i poświęcili się opiece nad chorymi lub niepełnosprawnymi. Dla osób z takim doświadczeniem myśl o byciu opiekunem była absurdalnym wynalazkiem społecznym. Ludzie, którzy byli w tej samej sytuacji jeszcze w latach 50 . nie uważaliby siebie nawet za wyróżniających się w sensie przynależności do specjalnej kategorii ludzi. Z tego właśnie powodu można myśleć o brytyjskiej koncepcji opiekuna jako o konstrukcie społecznym, kategorii stworzonej poprzez wzajemne oddziaływanie między indywidualnym doświadczeniem a różnymi grupami interesów - politykami, badaczami i grupami nacisku [22].

W 1981 roku nowo wybrany rząd konserwatywny zaczął promować „opiekę przez społeczność" (community care). Oficjalny dokument wydany przez Departament Zdrowia i Ubezpieczeń Społecznych (Department of Health and Social Security) potwierdzit, że podstawowe źródła wsparcia i opieki dla osób starszych są nieformalne i dobrowolne; pochodzą z osobistych więzi pokrewieństwa, przyjaźni i sąsiedztwa oraz są niezastąpione. Podkreślono jednak, że rolą władz publicznych jest utrzymanie $i, w$ razie potrzeby, rozwijanie - ale nigdy nie zastępowanie - takiego wsparcia i opieki [24]. Warto dodać, że pogląd ten podzielany był przez samych zainteresowanych oraz ich krewnych i przyjaciół. Po wprowadzeniu polityki przewidywano, że pieniądze zaoszczędzone na przepisach instytucjonalnych zostaną wykorzystane do stworzenia zintegrowanej sieci usług zdrowotnych i socjalnych w społeczności. Jednakże, pomimo wzrostu liczby tych usług, nadal uznawało się, że główne wsparcie dla osób zależnych w społeczności jest udzielane nieformalnie przez ich rodziny i przyjaciół [25].
Mimo że słowo „opiekun” nie pojawiło się wówczas w oficjalnych dokumentach, uznano, że opieka może wiązać się ze znacznym poświęceniem osobistym, zwłaszcza gdy "rodzina” oznacza przeważnie jedną osobę - często samotną kobietę, zajmującą się swoim starszym krewnym [24]. Koncepcja rządu i promowanie "opieki przez społeczność" były powszechnie interpretowane jako praca wykonywana przez kobietę. Na podstawie tego opracowano szereg badań naukowych, wiele raportów i seminariów otrzymało tytuły, takie jak "Troska o opiekuna", a termin ten zaczął być coraz częściej używany w oficjalnych dokumentach i do 1989 roku słowo „opiekun" zostało oficjalnie uznane w słownictwie fachowym [17, 22].

Warto w tym miejscu zauważyć, że również w polskiej literaturze przedmiotu zaczęły pojawiać się definicje opiekuna rodzinnego i nieformalnego, ale jak podkreśla Anna Janowicz "nie ma powszechnie obowiązujących definicji tych pojęć ani zgody w ich różnicowaniu wśród badaczy, polityków społecznych lub usługodawców. Można założyć, że opieka nieformalna jest pojęciem szerszym niż opieka rodzinna, bo oprócz członków rodziny obejmuje również wolontariuszy, sąsiadów i inne osoby $z$ lokalnych środowisk. Tematyka związana z sytuacją opiekunów nieformalnych pojawia się zwykle w kontekście organizacji opieki nad niesamodzielnymi osobami starszymi" [6]. Samo definiowanie tych ważnych pojęć w polskiej literaturze przedmiotu, ugruntowanych $w$ literaturze międzynarodowej, pozwala mieć nadzieję, że znajdą one miejsce w nauce i w praktyce opiekuńczej, a w konsekwencji - staną się powszechnie znane i używane także w Polsce.

\section{The 1985 General Household Survey — przełom po ogólnokrajowych badaniach opiekunów w Wielkiej Brytanii}

Na początku lat 70. XX wieku w Wielkiej Brytanii zaczęto zastanawiać się jak policzyć osoby, które sprawują opiekę nad innymi - bazowano więc na danych dotyczących liczby osób potrzebujących opieki. Szacowano wówczas, że może istnieć prawie milion osób dorosłych ze specjalnymi potrzebami, żyjących z innymi osobami, które, jak należało przypuszczać, zapewniały im przynajmniej pewne wsparcie. Łącznie z opiekunami, którzy wspierali ciężko niepełnosprawne dzieci, prawdopodobna liczba populacji opiekunów zbliżyła się do 1,2 milion [9].

Jednak przełomem w zrozumieniu nie tylko znaczenia słowa "opiekun”, ale także skali dotychczas niezauważanego problemu było Ogólne Badanie Gospodarstw Domowych przeprowadzone w 1985 roku 
w Wielkiej Brytanii (The 1985 General Household Survey). Na prośbę Departamentu Zdrowia i Ubezpieczeń Społecznych do ogólnej ankiety dotyczącej gospodarstw domowych włączono serię pytań w celu zidentyfikowania osób opiekujących się chorymi, niepełnosprawnymi lub starszymi. Głównym celem pytań było dostarczenie krajowych szacunków liczby osób, które zapewniały nieformalną opiekę tego rodzaju oraz liczby w różnych podgrupach opiekunów. Informacje zebrano z reprezentatywnej dla całego kraju próby około 18500 dorosłych mieszkających w prywatnych gospodarstwach domowych w Wielkiej Brytanii. Opiekunów definiowano jako osoby, które opiekowały się lub świadczyły regularne usługi dla chorej, niepełnosprawnej lub starszej osoby mieszkającej we własnym lub w innym gospodarstwie domowym [25].

Ogólne Badanie Gospodarstw Domowych z 1985 roku było pierwszym miarodajnym krajowym badaniem populacji opiekunów. Na tej podstawie oszacowano, że w Wielkiej Brytanii było wówczas 6 milionów opiekunów, z czego $40 \%$ stanowili mężczyźni. Obie statystyki były szokiem dla świata polityki. Dane te zostały jednak poddane w wątpliwość przez badaczy w kolejnych latach. Uważano, że termin "opieka" użyty podczas badania nie był precyzyjny i należy rozróżnić nieformalną opiekę od nieformalnej pomocy. Idąc tym tropem, ostatecznie uznano, że nieformalnych opiekunów w Wielkiej Brytanii jest 1,3-1,7 miliona. Badacze chcieli w ten sposób pomóc politykom zidentyfikować opiekunów, którzy potrzebują największego wsparcia praktycznego [22]. Badanie to było krokiem milowym w walce o prawa opiekunów, które sprawiło, że działania na rzecz wsparcia opiekunów zintensyfikowały się.

\section{Ustawa o opiekunach oraz działania organizacji Carers UK na przełomie XX i XXI wieku}

Po rozszerzeniu Zasiłku Opiekuńczego, formacji Krajowego Stowarzyszenia Opiekunów i imponującym badaniu populacji z 1985 roku generalne podejście do opiekunów zmieniło się. Pytaniem nie było już kto zapewnia opiekę, ale kim są opiekunowie. Tymczasem nowo powstałe stowarzyszenie z pomocą członka rządu, Malcolma Wicksa, skutecznie prowadziło kampanię w Parlamencie [22]. Wicks odniósł sukces i w 1995 roku Ustawa o opiekunach (Carers [Recognition and Services] Act 1995) [26] weszła do Dziennika Ustaw. Zgodnie z tą ustawą opiekun jest definiowany jako osoba, która regularnie zapewnia lub zamierza zapewnić opiekę odpowiedniej osobie [22].

Ustawa o opiekunach była pierwszym aktem prawnym, który nadał bezpośrednie prawo opiekunom do oceny ich potrzeb i które było odrębne od oceny potrzeb osób przyjmujących opiekę. Ustawa ta była ważnym osiągnięciem dla organizacji zajmujących się opiekunami, jednak ze względu na to, że lokalne władze nie przeznaczyły dodatkowych środków na wdrożenie wymogów nowego prawa jej wartość była bardziej symboliczna niż rzeczywista. Poziom usług dla opiekunów zaczął zmieniać się dopiero po 1997 roku wraz z wyborem nowego rządu, który zobowiązał się do przeznaczenia odpowiednich środków na rzecz opieki rodzinnej [17]. Ustawa o opiekunach od 1995 roku była głównym prawem przysługującym opiekunom osób niesamodzielnych w Wielkiej Brytanii, będąc swoistym podsumowaniem wysiłków osób i instytucji w XX wieku.

Warto też dodać, że Wicks w nowym prawie chciał uwzględnić wszystkich opiekunów, jednak musiał zacząć on od zidentyfikowania 3 konkretnych grup, najbardziej obciążonych sprawowaniem opieki. Wskazał on na dorosłych opiekujących się starszym krewnym, opiekunów swoich rodziców oraz opiekunów swoich niepełnosprawnych dzieci. Z początkowej liczby 6 milionów opiekunów Wicks skupił się na 1,5 miliona osób, które sprawowały opiekę przez 20 godzin tygodniowo lub dłużej - określił ich mianem „armii opiekunów" [27].

W międzyczasie, pod koniec XX wieku Krajowe Stowarzyszenie Opiekunów przekształciło się w nowoczesną organizację charytatywną, rozwijającą usługi dla opiekunów. Wiele oddziałów organizacji skupiło swoje wysiłki na tworzeniu dziesiątek lokalnych ośrodków opiekuńczych - wiele z nich nadal zapewnia niezbędne wsparcie. W 1997 roku organizacja uruchomiła pierwszą krajową infolinię dla opiekunów oraz wprowadziła pomoce w formie broszur i pisemnych informacji. Wśród stworzonych usług znalazły się projekty mające na celu pomoc opiekunom w powrocie do pracy i pomoc byłym opiekunom w radzeniu sobie z żałobą. W 2001 roku Krajowe Stowarzyszenie Opiekunów zmieniło swoją nazwę na Carers UK [19].

Timothy Cook, który przez wiele lat współpracował z Carers UK, a w roku 2007 napisał książkę The History of the Carers' Movement, wskazał na kilka głównych czynników, które przyczyniły się do sukcesu organizacji. Carers UK nie działało samodzielnie i na przestrzeni czasu, od początków swojego istnienia współpracowało $z$ ponad czterdziestoma innymi organizacjami. Kolejnym, bardzo istotnym czynnikiem były kampanie oparte przede wszystkim na badaniach i rozgłosie. Organizacja skupiała się na radiu, gazetach lokalnych i krajowych, a w późniejszym czasie na telewizji. Współpracowała również z agencją, która prowadzita doradztwo w sprawie technik reklamowych [28]. Chcieli dotrzeć do jak największej liczby odbiorców; 
posługiwali się mocnymi tytułami, które wzbudzały emocje; dzielili się prawdziwymi historiami opiekunów i co najważniejsze, wykorzystywali każdą okazję, aby to sami opiekunowie mogli się tymi historiami dzielić; stawiali ich w centrum swojej działalności [18].

Timothy Cook wspomina o jeszcze jednym, kluczowym elemencie, który wpłynął na duży sukces nie tylko Carers UK, ale i całego ruchu opiekunów. Już od 1965 roku organizacja bardzo silnie zaczęła angażować politykę w problem społeczny opieki rodzinnej i co ważne - niezmiennie pozostając politycznie neutralną. Cook wspomina, że organizacja ta stała się silną grupą lobbystyczną, która w swoich naciskach bazowała głównie na badaniach i liczbach, gdzie najważniejszą kwestią była wartość, jaką opiekunowie przynoszą państwu brytyjskiemu. W wywiadzie radiowym przeprowadzonym pod koniec lat 90 . XX wieku, premier Wielkie Brytanii Tony Blair potwierdzit, że opiekunowie nieformalni oszczędzają państwu brytyjskiemu 76 miliardów funtów rocznie [28].

Po wprowadzeniu Ustawy o opiekunach w 1997 Carers UK roku zmieniła swoje oblicze. Po wypełnieniu zadań adwokata na rzecz praw opiekunów i obowiązków społecznych wobec nich, u progu XXI wieku stała się organizacją wspierającą i monitorującą społeczne wsparcie. Carers UK do dnia dzisiejszego jest największą organizacją charytatywną wspomagającą opiekunów w Wielkiej Brytanii, świadomą swoich korzeni - konfederacją powstałą z różnych grup i instytucją kluczową w rozpoczętym $w$ drugiej połowie $X X$ wieku ruchu społecznym.

\section{Podsumowanie - inspiracje dlla polskich działań na rzecz opiekunów rodzinnych}

Historia ruchu opiekunów rodzinnych w Wielkiej Brytanii pokazuje jak trudna była walka o rozpoznanie i zrozumienie wyzwań, przed którymi stają sami opiekunowie rodzinni oraz polityka społeczna wobec potrzeb starzejącego się społeczeństwa. Julia Twigg w książce z 1992 roku Carers: research and practice podsumowuje skalę przemian u schyłku XX wieku, mówiąc, że 10 lat temu jej książka nie mogłaby zostać napisana, a 20 lat temu nikt nawet nie pomyślałby o takim temacie badań. Jest to miara zmian, które zaszły w kwestii opieki rodzinnej w ostatnich dekadach XX wieku w Zjednoczonym Królestwie [29]. Rozpoczęto w latach 60. od publikacji prasowych, kampanii i pytań: kim są opiekunowie. Stopniowo doszło do identyfikacji konkretnych grup osób potrzebujących wsparcia oraz do współpracy pierwszych organizacji z badaczami i politykami. Debata trwała i rozwijała się poprzez dyskusje o roli pomocy społecznej i grup wsparcia aż do planowanych strategii na przyszłość. Działania te doprowadziły do stworzenia nowych praw dla opiekunów i monitorowania ich implementacji w praktyce życia społecznego.

Analizując historię przemian kulturowych i społecznych oraz rozwój ruchu opiekunów rodzinnych w Wielkiej Brytanii, pojawia się pytanie o etap, na którym obecnie znajduje się Polska w kontekście opieki rodzinnej. Zapoznanie się z tłem historycznym i podobieństwami procesów zachodzących w Polsce pozwala w pewien sposób umiejscowić ją w biegu historii i wskazać na kolejne kroki w rozwoju krajowego ruchu opiekunów.

Wspomniane w artykule starzenie się społeczeństw oraz przemiany demograficzne, społeczne i kulturowe, które zaszły w Wielkiej Brytanii nie ominęły również Polski. Według danych statystycznych GUS w latach 1989-2014 liczba osób w wieku 60 lat i więcej wzrosła o około 2,9 miliona [30]. Procesy obserwowane w Polsce wskazują, że od lat 90. XX wieku spadła liczba urodzeń i zawieranych małżeństw, wzrosła liczba rozwodów i związków nieformalnych [31].

Warto też zauważyć, że opieka paliatywno-hospicyjna jest w Polsce, podobnie jak w Wielkiej Brytanii, bardzo dobrze rozwinięta. Według badań Atlas Europa z 2019 roku wynika, że Polska jest jednym z pierwszych krajów Wschodniej Europy, która wprowadziła system ogólnokrajowych, specjalistycznych usług w zakresie opieki paliatywnej i jest drugim krajem w Europie, po wielkiej Brytanii, z największą liczbą takich usług [32].

Skupiając się natomiast na samym problemie opieki rodzinnej, w Polsce najszerszą działalność w tym temacie realizuje Fundacja Hospicyjna z Gdańska, która od kilku lat z coraz większym powodzeniem prowadzi coroczne kampanie społeczne na rzecz opiekunów rodzinnych oraz obchody Dnia Opiekuna Rodzinnego [33]. Fundacja była również jednym z patronów pierwszego w Polsce badania opinii publicznej na temat opiekunów rodzinnych w 2016 roku, w którym udział wzięło ponad 1000 respondentów [34]. Jest też twórcą przewodnika internetowego dla opiekunów, który zawiera wiele cennych informacji dotyczących opieki, praktycznego wsparcia oraz działań fundacji na ich rzecz [35]. W ramach corocznej ogólnopolskiej kampanii Hospicjum to też życie od 2016 roku zaczęła zwracać uwagę na problem opiekunów rodzinnych. Fundacja od tego czasu przeprowadziła trzy kampanie pod nazwami Opiekun rodzinny - samotny bohater? oraz Opiekun rodzinny - nie musi być sam, które na celu miały rozszerzenie świadomości społecznej oraz praktyczne wsparcie opiekunów. Przeprowadzono warsztaty oraz spotkania edukacyjne dla opiekunów, skupiono się na rozwoju lokalnego wolontariatu, zwrócono uwagę Rzecznika Praw Obywatelskich, który 
zainterweniował w sprawie opiekunów w liście do Minister Rodziny, Pracy i Polityki Społecznej, uzyskano dofinansowanie na szkolenia dla opiekunów oraz rozpoczęto budowę centrum opieki wytchnieniowej w Gdańsku [33]. W 2019 roku termin „opieka wytchnieniowa" został oficjalnie włączony urzędowym pismem do działań rządowych, a ta forma pomocy jest prawnie przyznawana pierwszej grupie opiekunów rodzinnych. O fundusze mogą ubiegać się rodzice ciężko chorych i niepełnosprawnych dzieci [36]. Warto też wspomnieć o ogólnopolskim programie edukacyjnym „Damy Radę” realizowanym przez fundację Razem Zmieniamy Świat z Torunia. W ramach projektu fundacja stworzyła przewodnik internetowy dla opiekunów rodzinnych, organizuje bezpłatne warsztaty, wydaje bezpłatne poradniki oraz przygotowuje filmy instruktażowe [37]. W 2019 roku, z inicjatywy ośmiu organizacji pacjentów, powołany został Ogólnopolski Dzień Opiekuna, który obchodzony ma być 12 lutego każdego roku [38].

Powyższe krótkie porównanie przemian demograficznych, kulturowych, poziomu rozwoju opieki u kresu życia oraz formowanie się organizacji wspierających opiekunów rodzinnych pozwala stwierdzić, że Polska jest obecnie na etapie, na którym Wielka Brytania była w latach 80. XX wieku. Pomimo podjętych już działań jesteśmy na początku drogi do włączania opiekunów rodzinnych do zintegrowanego systemu opieki. Pilnym problemem do rozwiązania w Polsce jest integracja działań pomocy społecznej z opieką medyczną, włączająca działania wolontariatu i wspierająca opiekunów rodzinnych, co od lat sugerują badacze tego zagadnienia [39]. Polska musi znaleźć odpowiedź na wyzwania rosnącej populacji osób starszych i niesamodzielnych, a świadomość tych problemów w naszym kraju jest na wczesnym etapie dyskursu społecznego. Dlatego kolejne działania na rzecz integracji opieki i wsparcia opiekunów rodzinnych warto modelować na podstawie dobrych praktyk wypracowanych przez Carers $U K$, od lat z powodzeniem realizowanych w brytyjskim społeczeństwie. Początki, rozwój i reorganizacje w strukturach Carers UK, wpływ tych przemian na przedstawicieli rządu i badaczy oraz ich konkretnych działań na rzecz opiekunów rodzinnych w Wielkiej Brytanii mogą być inspiracją do kolejnych kroków, które należy podjąć w Polsce. Działaniom organizacji wspierających opiekunów rodzinnych w Wielkiej Brytanii, a także najnowsze inicjatywy ruchu opiekunów nieformalnych w XXI wieku będą tematem kolejnego doniesienia przygotowywanego przez autorkę dla polskich czytelników, ukazującego aktualne wyzwania opieki rodzinnej i sposoby odpowiedzi na nie.

\section{Konflikt interesów}

Autorka deklaruje brak konfliktu interesów.

\section{Finansowanie}

Badanie nie było finansowane. 